\title{
Production of Passion fruit in a semi-hydroponic system under protected cultivation
}

\author{
Douglas José Marques ${ }^{1}$, José Andres Carreño Siqueira ${ }^{2}$, \\ Hudson Carvalho Bianchini ${ }^{1}$, Vinicius Mendes Alves ${ }^{2}$
}

\begin{abstract}
The objective of this research was to evaluate the production of passion fruit (Passiflora edulis Sims) cultivars in different nutrient solutions, using commercial Bioplan ${ }^{\text {tब }}$ substrate in slabs system in protected cultivation. A randomized complete block design in a factorial scheme was used with 2 passion fruit cultivars (Araguari and Yellow Master) $\mathrm{x} 4$ nutrient solutions (solution 1, solution 2, solution 3 and solution 4), each plot consisting of 6 plants with 6 replications. Electrical conductivity evaluations in the slabs drained solution started at 15 days after seedling transplantation and the nutrient contents were quantified at the end of the research. In passion fruit, ether extract, crude fiber and crude protein were evaluated. Fruit number, pulp mass, peel thickness and gas exchange were evaluated. It was concluded that the use of nutrient solution 2 in cultivar Yellow Master, with $2.72 \mathrm{dS} \mathrm{m}^{-1}$ electrical conductivity and the use of nutrient solution 4 in cultivar Araguari, with $2.95 \mathrm{dS} \mathrm{m}^{-1}$ electrical conductivity, yielded the largest number of fruits, pulp mass, fruit mass and gas exchange, in slabs system in the protected cultivation of passion fruit. Index terms: Nutrition solutions, fruit farming, slabs.
\end{abstract}

\section{Produção de Maracujá em sistema semi-hidropônico no cultivo protegido}

Corresponding author: douglasjmarques81@yahoo.com.br

Received: May 28, 2019 Accepted: August 16, 2019

Copyright: All the contents of this journal, except where otherwise noted, is licensed under a Creative Commons Attribution License.

\begin{abstract}
Resumo-O objetivo da pesquisa foi avaliar a produção de cultivares de maracujazeiro (Passiflora edulis Sims) em diferentes soluções nutritivas, usando substrato comercial Bioplant ${ }^{\circledR}$ em sistema $^{-}$ slabs no cultivo protegido. Foi utilizado o delineamento em blocos casualizados, em esquema fatorial, com 2 cultivares de maracujá (Araguari e Yellow Master) x 4 soluções nutritivas (solução 1 , solução 2, solução 3 e solução 4), cada parcela constituída por 6 plantas, com 6 repetições. As avaliações da condutividade elétrica na solução drenada dos slabs iniciaram aos 15 dias após o transplantio das mudas e os teores de nutrientes foram quantificados ao final da pesquisa. Nos frutos do maracujá foram avaliados extrato etéreo, fibra bruta e proteína bruta. Avaliou-se número de frutos, massa da polpa, espessura da casca e as trocas gasosas. Conclui-se que o uso da solução nutritiva 2 na cultivar Yellow Master, com condutividade elétrica de 2,72 $\mathrm{dS} \mathrm{m}^{-1}$ e o uso da solução nutritiva 4 na cultivar Araguari, com a condutividade elétrica 2,95 $\mathrm{dS} \mathrm{m}^{-1}$, proporcionaram o maior número de frutos, massa da polpa, massa dos frutos e as trocas gasosas, em sistema slabs no cultivo protegido do maracujazeiro.
\end{abstract}

Termo de indexação: Soluções nutritivas, fruticultura, slabs. 


\section{Introduction}

Yellow passion fruit (Passiflora edulis Sims) is the main species of the Passifloraceae family grown in Brazil, due to the physicochemical characteristics of the fruits, high yield and acceptance of the juice in the national market (SANTOS et al., 2014). Brazil is a reference in passion fruit production, with 555 thousand tons. and average yield of $13.50 \mathrm{t}^{\mathrm{h}} \mathrm{ha}^{-1}$ year ${ }^{-1}$, highlighting the Northeast region, with $60 \%$ of national production and produced quantity of 295 thousand tons. The state of Bahia leads the ranking with 170 thousand tons of produced fruits (IBGE, 2017).

The semi-hydroponic substrate production system is an adaptation of the hydroponic system, where the soil is replaced by the use of nutrient solutions, providing a lower environmental impact and more efficient use of water and nutrients (SOARES et al., 2007). What distinguishes the semi-hydroponic system is the use of inert substrate to support the plant, nourished through fertigation as in the case of the conventional hydroponic system (RODRIGUES, 2002). Among the advantages of using this system are the reduced incidence of pests and diseases, the elimination of the need for rotation (makes monoculture viable) and the possibility of achieving better fruit quality.

For substrate conditioning, slabs, also known as planting bags or plastic containers made of polymer, can be used, offering advantages for farmers such as ease of use in smaller areas intercrop production and reduced production cost. The use of slabs may also represent an option in regions where the soil is contaminated or when weather conditions are not ideal for cultivation (GONÇALVES et al., 2016), being an efficient alternative to overcome soil pathogen-related problems.

The quality of passion fruit is influenced by factors related to cultivars, climate, soil and cultural practices, including fertilization and irrigation (ROCHA et al., 2013). Nutrients must be applied at levels compatible with plant requirements, emphasizing that the use of fertigation (application via irrigation water) is proven effective (BORGES et al., 2006).

Most orchards for passion fruit production are in small family farms, and research is necessary to benefit and favor these small producers. Over the years, the crop has been shown to be an alternative income for small and medium rural producers, due to the value of the marketed fruits (SANTOS et al., 2017). However, the diversity of diseases that can be established in the soil, besides the presence of nematodes, sometimes forces many producers to choose to plant other crops, or even to leave these areas.

Given the difficulties faced by producers to conduct this crop, this research aimed to evaluate the production of passion fruit cultivars in different nutrient solutions, using slabs substrate under protected cultivation.

\section{Material and Methods}

The experiment began in January 2016 and was conducted until December 2018, under protected cultivation in a greenhouse, with 225 meters (9 meters wide by 25 meters long) and ceiling height of 4 meters, covered with agrofilm (150 microns).

Two passion fruit cultivars were used: 'Araguari' (FB 300) and 'Yellow Master' (FB 200), sown in 128cell polystyrene trays on a commercial pine bark- and vermiculite-based Bioplant ${ }^{\mathbb{B}}$ substrate, at a ratio of 1:1 $(\mathrm{v} / \mathrm{v})$, for about 30 days.

At 45 days after sowing, when the seedlings had three pairs of definitive leaves, transplantation was performed in plastic containers (slabs). The seedlings were placed into the slabs in openings previously made with a preheated circular drill, using a seedling in each slab. The use of six plants per treatment was standardized, discarding the edges of the plots as borders. In $45-\mathrm{cm}$ slabs, the substrate was conditioned with the following chemical characterization: aluminum $=0.1 \mathrm{mg} \mathrm{dm} ;$; calcium $=2.0 \mathrm{mg}$ $\mathrm{dm}^{3} ;$ magnesium $=1.0 \mathrm{mg} \mathrm{dm} 3$; potassium $=7.0 \mathrm{mg} \mathrm{dm}$; phosphorus $=55 \mathrm{mg} \mathrm{dm}^{3} ;$ sulfur $=170 \mathrm{mg} \mathrm{dm}^{3} ;$ sodium $=42$ $\mathrm{mg} \mathrm{dm} 3$; boron $=1.2 \mathrm{mg} \mathrm{dm}^{3}$; iron $=5 \mathrm{mg} \mathrm{dm}^{3}$; manganese $=$ $0.1 \mathrm{mg} \mathrm{dm}^{3}$; copper $=0.2 \mathrm{mg} \mathrm{dm}^{3}$; zinc $=0.2 \mathrm{mg} \mathrm{dm}^{3}$. The slabs were distributed in 1-m spacing between plants and $2.5 \mathrm{~m}$ between lines.

The image of the experiment set in the greenhouse slabs system can be seen in Figure 1.

Pruning started about 20 days after transplanting, eliminating the lateral shoots, leaving only the most vigorous branch, led by a tutor until the end of the wire. During the off-season, cleaning pruning was done, removing the dry and/or diseased branches, to provide better aeration to the passion fruit foliage.

Artificial pollination was done by transferring the pollen grains from one flower to another, with the fingers in the afternoon, during the period of greatest flowering, two to three times a week.

During plant development, there was no need to apply phytosanitary products for pest and disease control.

A completely randomized design was used, in a factorial scheme with 2 cultivars. ('Araguari' and 'Yellow Master') and 4 nutrient solutions (solution 1, solution 2, solution 3 and solution 4), with 6 replicates. The nutrient solutions followed the recommendation of Marques et al. (2018), with adaptations. The amount of nutrients used in the solution was: Solution $1=\mathrm{N}^{-N^{-}}=145 \mathrm{mg} \mathrm{L}^{-1}$, phosphorus $=29 \mathrm{mg} \mathrm{L}^{-1}$; potassium $=40 \mathrm{mg} \mathrm{L}^{-1}$; calcium $=$ $295 \mathrm{mg} \mathrm{L}^{-1}$; magnesium $=163 \mathrm{mg} \mathrm{L}^{-1}$; sulfur $=40 \mathrm{mg} \mathrm{L}^{-1}$; boron $=0.64 \mathrm{mg} \mathrm{L}^{-1}$; copper $=0.2 \mathrm{mg} \mathrm{L}^{-1}$; iron $=0.3 \mathrm{mg} \mathrm{L}^{-1}$; manganese $=1.0 \mathrm{mg} \mathrm{L}^{-1} ;$ molybdenum $=0.05 \mathrm{mg} \mathrm{L}^{-1}$; zinc $=$ $0.3 \mathrm{mg} \mathrm{L}^{-1}$. Solution $2=\mathrm{N}^{-\mathrm{NO}_{3}}=169 \mathrm{mg} \mathrm{L}^{-1}$, phosphorus $=$ $62 \mathrm{mg} \mathrm{L}^{-1}$; potassium $=311 \mathrm{mg} \mathrm{L}^{-1}$; calcium $=153 \mathrm{mg} \mathrm{L}^{-1}$; magnesium $=43 \mathrm{mg} \mathrm{L}^{-1}$; sulfur $=50 \mathrm{mg} \mathrm{L}^{-1}$; boron $=0.2 \mathrm{mg}$ $\mathrm{L}^{-1}$; copper $=0.03 \mathrm{mg} \mathrm{L}^{-1}$; iron $=4.3 \mathrm{mg} \mathrm{L}^{-1}$; manganese $=$ 
$1.1 \mathrm{mg} \mathrm{L}^{-1}$; molybdenum $=0.05 \mathrm{mg} \mathrm{L}^{-1}$; zinc $=0.3 \mathrm{mg}$ $\mathrm{L}^{-1}$. Solution $3=\mathrm{N}-\mathrm{NO}_{3}=174 \mathrm{mg} \mathrm{L}^{-1}$, phosphorus $=56$ $\mathrm{mg} \mathrm{L}{ }^{-1}$; potassium $=258 \mathrm{mg} \mathrm{L}^{-1}$; calcium $=153 \mathrm{mg} \mathrm{L}^{-1}$; magnesium $=41 \mathrm{mg} \mathrm{L}^{-1}$; sulfur $=54 \mathrm{mg} \mathrm{L}^{-1}$; boron $=0.2 \mathrm{mg}$ $\mathrm{L}^{-1}$; copper $=0.03 \mathrm{mg} \mathrm{L}^{-1}$; iron $=2.5 \mathrm{mg} \mathrm{L}^{-1}$; manganese $=$ $0.4 \mathrm{mg} \mathrm{L}^{-1}$; molybdenum $=0.05 \mathrm{mg} \mathrm{L}^{-1}$; zinc $=0.3 \mathrm{mg} \mathrm{L}^{-1}$. Solution $4=\mathrm{N}^{-\mathrm{NO}_{3}}=125 \mathrm{mg} \mathrm{L}^{-1}$, phosphorus $=46 \mathrm{mg} \mathrm{L}^{-1}$; potassium $=176 \mathrm{mg} \mathrm{L}^{-1}$; calcium $=119 \mathrm{mg} \mathrm{L}^{-1}$; magnesium $=$ $24 \mathrm{mg} \mathrm{L}^{-1}$; sulfur $=32 \mathrm{mg} \mathrm{L}^{-1}$; boron $=0.2 \mathrm{mg} \mathrm{L}^{-1}$; copper $=$ $0.03 \mathrm{mg} \mathrm{L}^{-1}$; iron $=2.5 \mathrm{mg} \mathrm{L}^{-1}$; manganese $=0.4 \mathrm{mg} \mathrm{L}^{-1}$; molybdenum $=0.05 \mathrm{mg} \mathrm{L}^{-1}$; zinc $=0.3 \mathrm{mg} \mathrm{L}^{-1}$. The different phenological phases of passion fruit were also considered for nutrient application. The solutions were previously prepared in the laboratory and stored in an amber flask (stock solution). The nutrient solution was managed daily in the late afternoon (5 o'clock). In the early morning ( 8 o'clock), electrical conductivity and $\mathrm{pH}$ measurements were performed to optimal values ( $\mathrm{pH}$ 6.5), completing the solution volume. The irrigation system was assembled based on four 100-L tanks. The fertigation system used was called "by pass" and the different nutrient solutions in the treatments were applied via irrigation water, at three distinct stages. During the first stage, the irrigation system was operated to hydraulically balance the irrigation units as a whole. In the second stage, the fertilizer was injected into the irrigation system through appropriate equipment. In the third stage, the system continued to work, aiming at complementing the total irrigation time, complete system washing, favoring fertilizer carriage. Water passing through the tank solubilizes and drags fertilizers. Samples of the solutions applied to the tanks and drained in the slabs were collected and identified and sent to the chemical analysis laboratory for the stoichiometric quantification of the nutrients. The electrical conductivity of nutrient solutions was quantified using a digital conductivity meter (CD-4303, Lutron).

Samples for quantification of nitrate, potassium, calcium and magnesium from the solutions, after fertigation, in the two passion fruit cultivars, were collected from slabs, stored in Falcon tubes and stored in a refrigerator. Nitrate $\left(\mathrm{NO}_{3}^{-}\right)$was determined using the Merck kit, which is a colorimetric test quantified on a photocolorimeter with a $400 \mathrm{~nm}$ LED. Potassium (K) was measured in an atomic absorption spectrometer, in $0.2 \mathrm{~nm}$ slit emission mode and at $766.5 \mathrm{~nm}$ wavelength. Calcium and magnesium $\left(\mathrm{Ca}^{2+}\right.$ and $\left.\mathrm{Mg}^{2+}\right)$ were analyzed by titration against EDTA, with Murexide as an indicator for $\mathrm{Ca}$ and Eriochrome Black $\mathrm{T}$ as an indicator for $\mathrm{Mg}$ (RICE; BRIDGEWATER, 2012).

Chemical-bromatological analyzes were performed in the bromatology laboratory, according to the methodology described by Silva and Queiroz (2002). The samples were pre-dried in a forced air oven at 55 ${ }^{\circ} \mathrm{C}$ for 72 hours. After pre-drying, the samples were milled in a Willey mill, with a $1 \mathrm{~mm}$ sieve and stored in plastic containers with lids. Total dry matter (DM) was determined by drying in a forced ventilation oven at 105 ${ }^{\circ} \mathrm{C}$ for 16 hours. Crude protein (CP) was determined according to the methodology proposed by Kjeldahl, using a micro-Kjeldahl distiller (AOAC, 1990; method 984.13); thus, the sample was digested, distilled and titrated in $0.1 \mathrm{~N} \mathrm{HCl}$. For total nitrogen quantification, it was then multiplied by the correction factor 6.25 to obtain the $\mathrm{CP}$ content, according to Equation 1. $\mathrm{CP} \%=\left[\mathrm{V}_{1}-\mathrm{V}_{2}\right] \times \mathrm{Fc} \times \mathrm{N}$ x $6.25 \times 0.014] / \mathrm{p} \times 100$ (Equation 1).

Where, $\mathrm{V} 1=$ Volume of $0.1 \mathrm{~N} \mathrm{HCl}$ spent in titration; $\mathrm{V} 2=$ Volume of $0.1 \mathrm{~N} \mathrm{HCl}$ spent on the blank test; $\mathrm{N}=$ Normality; $p=$ Sample mass in grams; $6.25=$ Nitrogen correction factor in protein and $0.014=$ milliequivalentgram of nitrogen. The ether extract (EE) content was determined by the heat method in a Goldfisch $\left(\right.$ Tecnal $\left.{ }^{\circledR}\right)$ apparatus using petroleum ether. The fibrous fraction of the sample was analyzed for crude fiber (CF) content, with the aid of a Tecnal ${ }^{\circledR}$ apparatus. Thus, $0.5 \mathrm{~g}$ of the previously weighed dry TNT sachet sample was weighed, subjected to acid $\left(\mathrm{H}_{2} \mathrm{SO}_{4}-1.25 \%\right)$ and basic $(\mathrm{NaOH}-1.25 \%)$ digestion for 30 minutes at $90{ }^{\circ} \mathrm{C}$. Subsequently, three washes in distilled water and one wash with acetone to remove any digestion residue were performed.

Net photosynthesis and transpiration rates, stomatal conductance and water use efficiency were analyzed in October 2018, using an LI-6400XT IRGA apparatus (Li-Cor, Lincoln, Nebraska, USA). Once it is a species that has many leaves, 10 leaves were used to make the measurement, totaling six measurements, defining the sixth top-down, fully expanded and mature leaf as the sampling unit. The value of $850 \mu \mathrm{mol} \mathrm{m}^{-2} \mathrm{~s}^{-1}$ saturation irradiance was set, defined by performing a light curve, choosing to use the radiation value that induced the maximum photosynthesis. Therefore, the IRGA camera temperature was controlled at $28^{\circ} \mathrm{C}$, since the maximum photosynthesis rate is achieved at relatively low radiation intensities, causing no destruction or damage to the photosynthetic apparatus. Measurements were performed on an area of $6 \mathrm{~cm}^{2}$ of the leaf at 8 o'clock.

Passion fruit harvest started in the second year after transplantation, according to the phenological development of the crop, when the ripe fruits fell to the ground. After fruit harvest, peel thickness was quantified, and the pulps were taken from 15 fruits and packed in hermetically sealed plastic pots and stored in a refrigerator at $2 \pm 2{ }^{\circ} \mathrm{C}$. To obtain the dry matter content of the samples, the pulps were placed in a lyophilizer to be dried and then the dry mass of the pulp samples was determined.

The results obtained in each of the experiments were submitted to analysis of variance and the means were submitted to the Tukey test, using the SISVAR software, according to the theories recommended by Ferreira (2011). 


\section{Results and Discussion}

The highest electrical conductivity (EC) of nutrient solutions collected in the tank before fertigation was observed in solution $4\left(3.95 \mathrm{dS} \mathrm{cm}^{-1}\right)$ (Figure 2A). The highest $\mathrm{EC}$ of the substrate drained solutions at the end of the research were observed for 'Yellow Master' in all solutions (Figure 2B). For 'Araguari', the highest EC values (Figure $2 \mathrm{C}$ ) were observed in solutions 1 and $3\left(0.48\right.$ and $\left.0.49 \mathrm{dS} \mathrm{cm}^{-1}\right)$ and, for 'Yellow Master', in solutions $2\left(0.43 \mathrm{dS} \mathrm{cm}^{-1}\right)$. and $4\left(0.66 \mathrm{dS} \mathrm{cm}^{-1}\right)$. Due to the lack of information on passion fruit cultivation in a semi-hydroponic system, the EC values of other crops were used as a reference. In the case of lettuce (Lactuca sativa), EC is generally between 2.23 and $2.64 \mathrm{dS} \mathrm{cm}^{-1}$ (FERNANDES et al., 2002); for strawberry (Fragaria $\mathrm{x}$ ananassa), $\mathrm{EC}$ is between 1.5 and $2.0 \mathrm{dS} \mathrm{cm}^{-1}$ (CALVETE et al., 2007); for tomato (Licopersicon esculentum), solutions with 1.1 to $1.2 \mathrm{dS} \mathrm{cm}^{-1} \mathrm{EC}$ in the early phase of the plant are recommended, and EC from 1.8 to 2.5 $\mathrm{dS} \mathrm{cm}{ }^{-1}$ in fruiting (FERNANDES et al., 2002). It was observed that solution 4 presented higher EC compared to all other nutrient solutions used. Costa et al. (2001) used saline water with $3.2 \mathrm{dS} \mathrm{cm}^{-1} \mathrm{EC}$ in passion fruit irrigation, and observed little influence on crop development. These results corroborate those found in this research.

The highest nitrate contents in the slabs drained nutrient solution (Figure 3A) were obtained when using solutions 1 and 4 ( 2.33 and $2.00 \mathrm{mg} \mathrm{L}$ ) for 'Araguari', when compared with solutions 2 and $3(6.2$ and $2.7 \mathrm{mg}$ L) for 'Yellow Master', which presented the highest contents. Regarding K content, 'Araguari' showed higher contents for solutions 1 and 2 (90.60 and $97.20 \mathrm{mg} \mathrm{L}$ ), while for solutions 2 (97.46 $\mathrm{mg} \mathrm{L}$ ) and 4 (90.06 mg). L), the highest content was found in 'Yellow Master' (Figure 3B). The content of $\mathrm{Ca}$ in the drained solution was higher in solutions 1 ( $40.33 \mathrm{mg} \mathrm{L}$ ) and 3 (48.66 $\mathrm{mg} \mathrm{L}$ ) for 'Yellow Master' and in solution 1 (32.00 mg L) for 'Araguari' (Figure 3C). For Mg contents, 'Yellow Master' had higher contents in solutions $2(22.00 \mathrm{mg} \mathrm{L}), 3(21.00 \mathrm{mg} \mathrm{L})$ and 4 (22.00 mg L). In 'Araguari' (Figure 3D), the highest Ca content was observed in solution 1 (20.00 $\mathrm{mg} \mathrm{L})$. These results indicate that there is a variation in nutrient uptake as a function of the different nutrient solutions and cultivars studied. According to Almeida et al. (2006) and Fortaleza et al. (2005), passion fruit is very efficient to absorb $\mathrm{N}$ and $\mathrm{K}$ of the nutrient solution. In research by Haag et al. (1973), in which nutrient uptake by yellow and purple passion fruit plants was evaluated, during the phases of higher plant physiological maturity, a high uptake of $\mathrm{N}$, $\mathrm{K}$ and $\mathrm{Ca}$ was observed.

The ether extract (EE) content did not range in the evaluated solutions and cultivars (Figure 4A). The crude fiber (CF) content (Figure 4B) increased in solution 3 for 'Yellow Master' $(0.42 \%)$ and in solution 4 for 'Araguari' (0.43). These results are in agreement with those obtained by Uchoa et al. (2008) in residues of the frozen fruit industry (seeds and peel), where significant levels of CF were detected in passion fruit pulp. Neiva Junior et al. (2007), who analyzed the residues of various crops for animal feed, found a considerable amount of $\mathrm{CF}$ in passion fruit. The crude protein (CP) content (Figure 4C) was higher for 'Araguari' (1.5\%) in nutrient solution 2 and for 'Yellow Master' (2.0\%) in solutions 3 and 4.

The highest pulp masses (Figure 5A) were obtained for 'Yellow Master' in solutions 1 and 2, with an average mass of (184.56 and $214.50 \mathrm{~g}$ fruit $\left.^{-1}\right)$, when compared to 'Araguari' in solutions 3 (97.60 $\left.\mathrm{g} \mathrm{fruit}^{-1}\right)$ and 4 (122.74 $\mathrm{g} \mathrm{fruit}^{-1}$ ). The highest peel thickness (Figure 5B) was obtained for 'Araguari' in solutions 3 and 4 and, for 'Yellow Master', in solutions 1 and 2. For peel mass (Figure 5C), nutrient solutions 1 (196.86 $\mathrm{g} \mathrm{fruit}^{-1}$ ) and 2 (188.56 $\left.\mathrm{g} \mathrm{fruit}^{-1}\right)$ showed the highest values in 'Yellow Master'; in 'Araguari', the highest values were obtained with solutions 3 (103.52 $\mathrm{g}$ fruit $\left.^{-1}\right)$ and $4\left(118.13 \mathrm{~g}_{\text {fruit }}{ }^{-1}\right)$. The results indicate that solutions 1 and 2 were more suitable for 'Yellow Master' and solutions 3 and 4, for 'Araguari'. Comparing the results obtained in this research with those found by Borges et al. (2003), who performed fertilization tests on yellow passion fruit (Passiflora edulis Sims f. flavicarpa Deg.), there is a disagreement about the results obtained for fruit mass. There was an agreement regarding potassium fertilization, whose concentration was higher in solution 1 , since the results showed that the peel mass was higher with the use of solution 1, which is more concentrated in $\mathrm{K}_{2} \mathrm{O}$ in 'Yellow Master' and indifferent in 'Araguari'.

The number of fruits (Figure 6A) was higher for 'Yellow Master' in solution 2 (19 fruits plant ${ }^{-1}$ year $\left.^{-1}\right)$; for the other solutions, there was no significant difference. Fruit mass (Figure 6B) was higher for 'Yellow Master' in solutions 1 (388.95 $\mathrm{g} \mathrm{plant}^{-1}$ year $\left.^{-1}\right)$ and 2 (427 g plant $^{-1}$ year $\left.^{-1}\right)$ and, in 'Araguari', in solutions 3. (189.67 $\mathrm{g} \mathrm{plant}^{-1}$ year $\left.{ }^{-1}\right)$ and 4 (245.16 g plant $^{-1}$ year $\left.^{-1}\right)$. These results are in agreement with that obtained by Sousa et al. (2003), who demonstrated that higher $\mathrm{K}$ concentrations can increase passion fruit yield.

Figure 7 shows the values of gas exchange in the passion fruit crop, as a function of nutrient solutions and cultivars. The highest net photosynthesis rates (Figure 7A), transpiration (Figure 7B), stomatal conductance (Figure 7C) and water use efficiency (Figure 7D) were observed in 'Yellow Master' in different nutrient solutions. The higher fruit production obtained for 'Yellow Master' is related to the higher gas exchange found. These results are also related to stomatal behavior, which determines the demand for transpiration, controlling the loss of leaf $\mathrm{H}_{2} \mathrm{O}$ to the environment (LIMA et al., 2010). Net photosynthesis is an indicator of carbon assimilation rate (POPOV et al., 2003), and agricultural yield is influenced by morphological and physiological characteristics of photosynthetic organs, such as leaves, and photoassimilate-consuming organs, known as drains. 


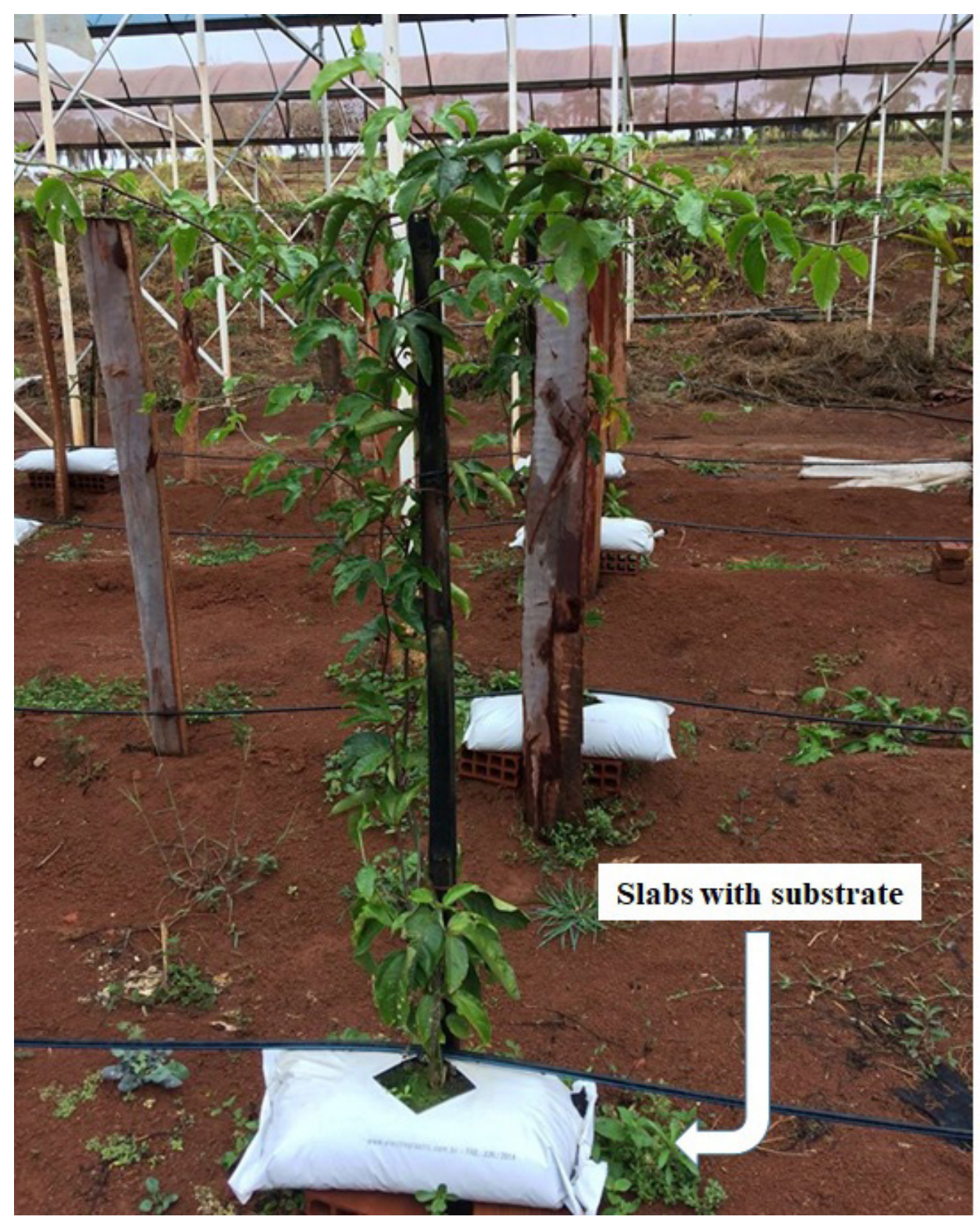

Figure 1. Passion fruit conditioned in slabs. 

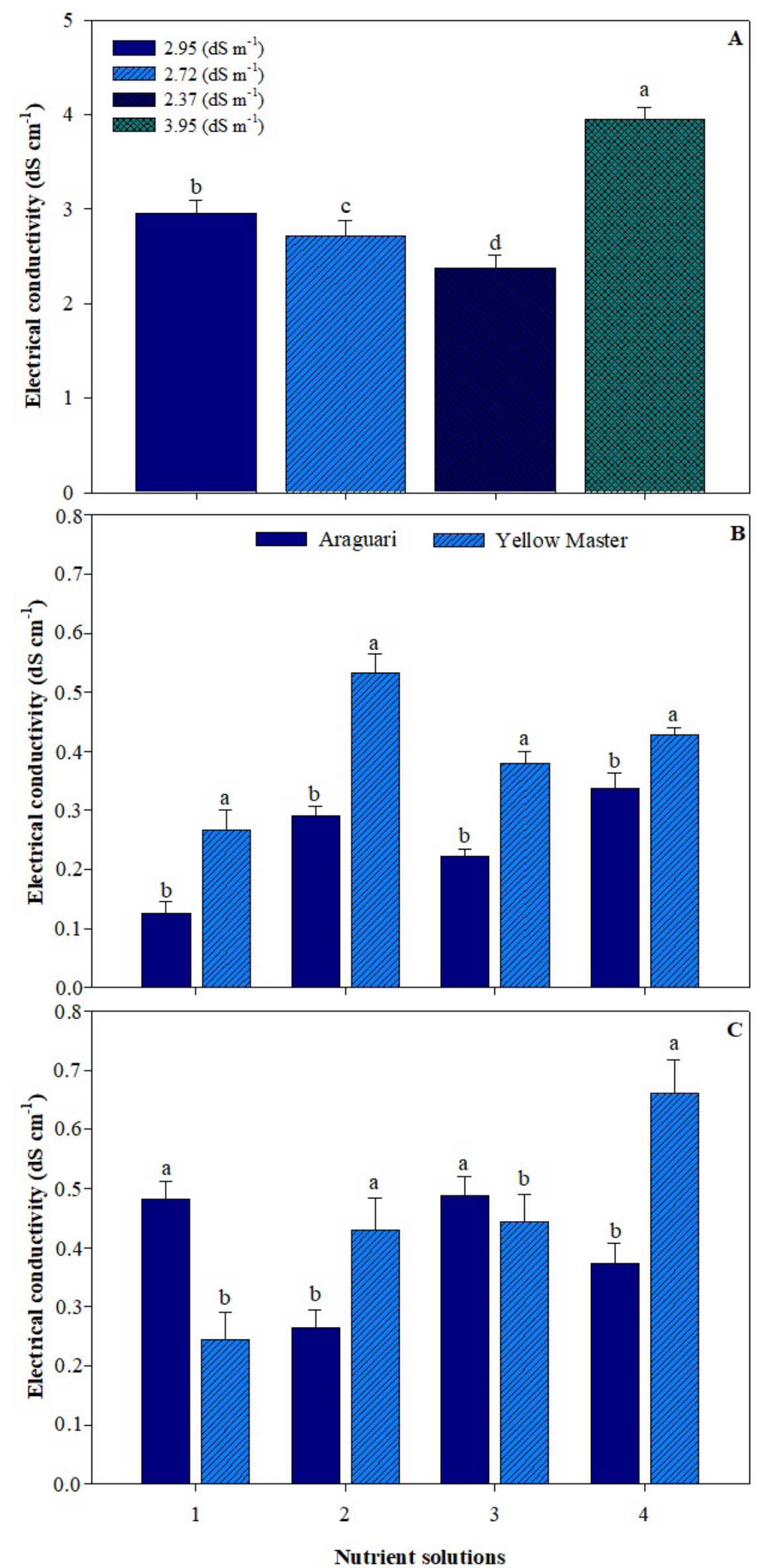

Figure 2. Electrical conductivity (EC) of substrate nutrient solutions (Figure A) at the end of the research (Figure B) and slabs drained during fertigation (Figure C), as a function of nutrient solutions and cultivars. Means followed by the same letter show no significant differences by the Tukey test at $5 \%$ probability $(\mathrm{P}>0.05)$. 


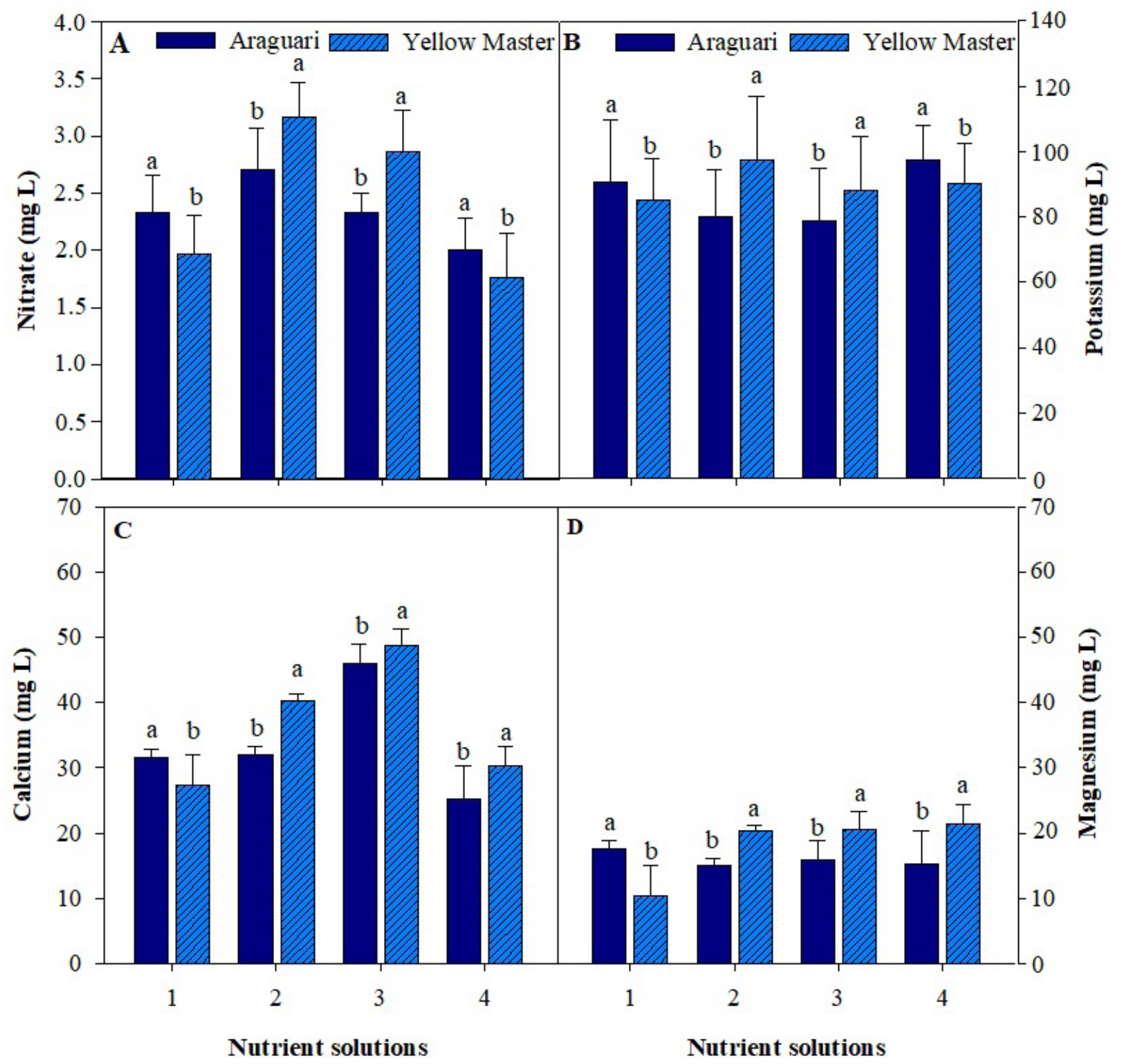

Figure 3. Quantification of nitrate (Figure A), potassium (Figure B), calcium (Figure C) and magnesium (Figure D) of solutions after fertigation, as a function of nutrient solutions and passion fruit cultivars. Means followed by the same letter show no significant differences by the Tukey test at $5 \%$ probability $(\mathrm{P}>0.05)$. 

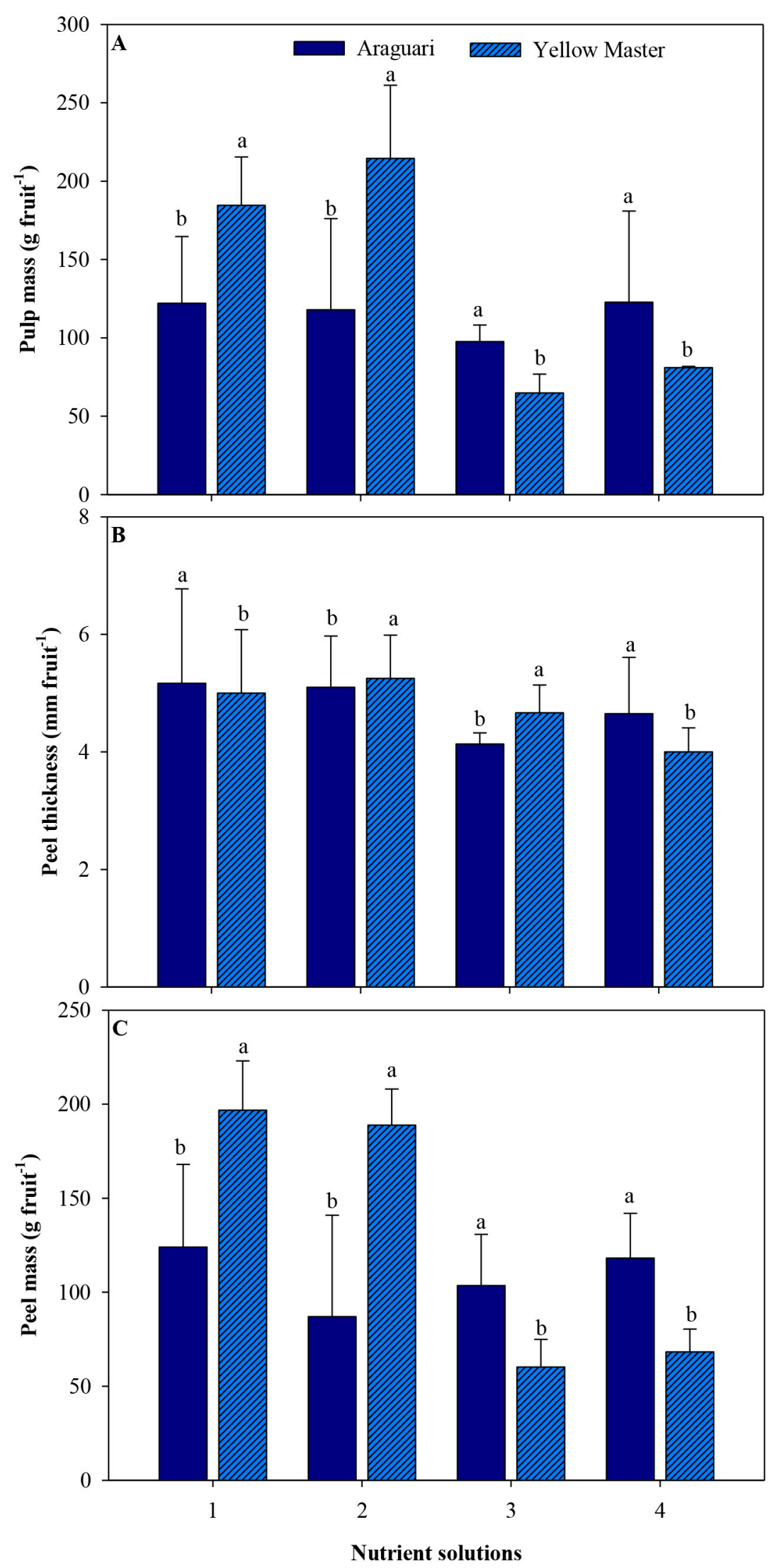

Figure 4. Dry matter (DM) of ether extract (Figure A), crude fiber (Figure B) and crude protein (Figure C) of passion fruit as a function of nutrient solutions and cultivars. Means followed by the same letter show no significant differences by the Tukey test at $5 \%$ probability $(\mathrm{P}>0.05)$. 

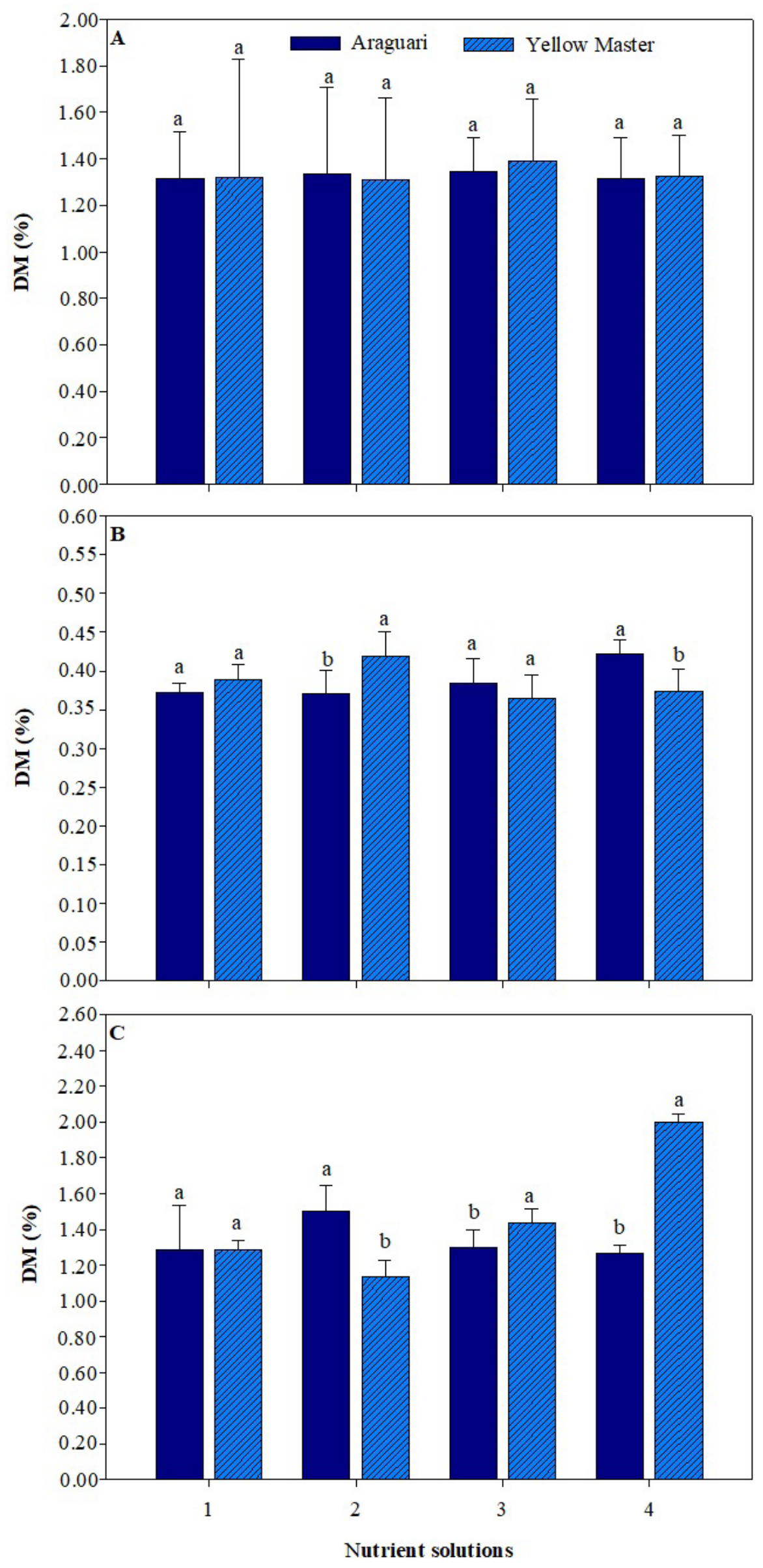

Figure 5. Pulp mass (Figure A), peel thickness (Figure B) and peel mass (Figure C) of passion fruit as a function of nutrient solutions. Means followed by the same letter show no significant differences by the Tukey test at $5 \%$ probability $(\mathrm{P}>0.05)$. 


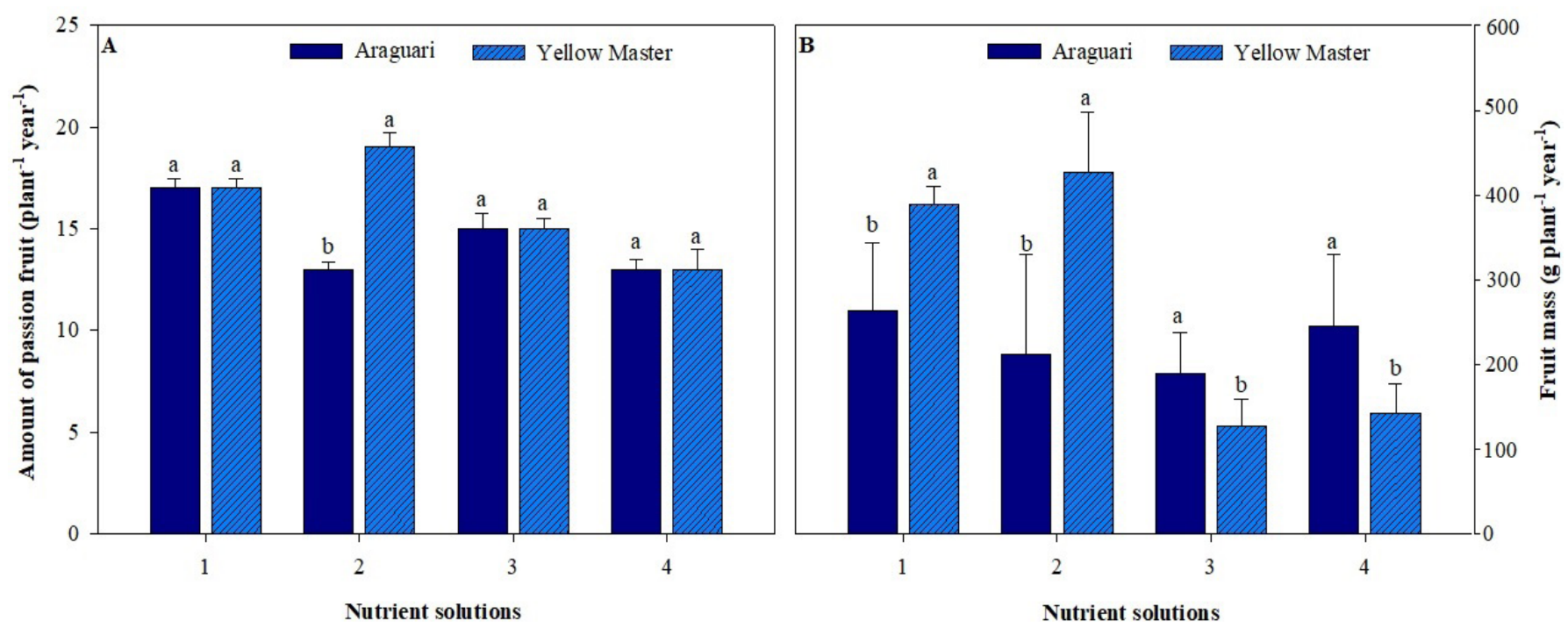

Figure 6. Amount of passion fruit (plant ${ }^{-1}$ year $\left.^{-1}\right)$ (Figure A) and fruit mass $\left(\mathrm{g} \mathrm{plant}^{-1}\right.$ year ${ }^{-1}$ ) (Figure B) as a function of nutrient solutions and cultivars. Means followed by the same letter show no significant differences by the Tukey test at $5 \%$ probability $(\mathrm{P}>0.05)$.
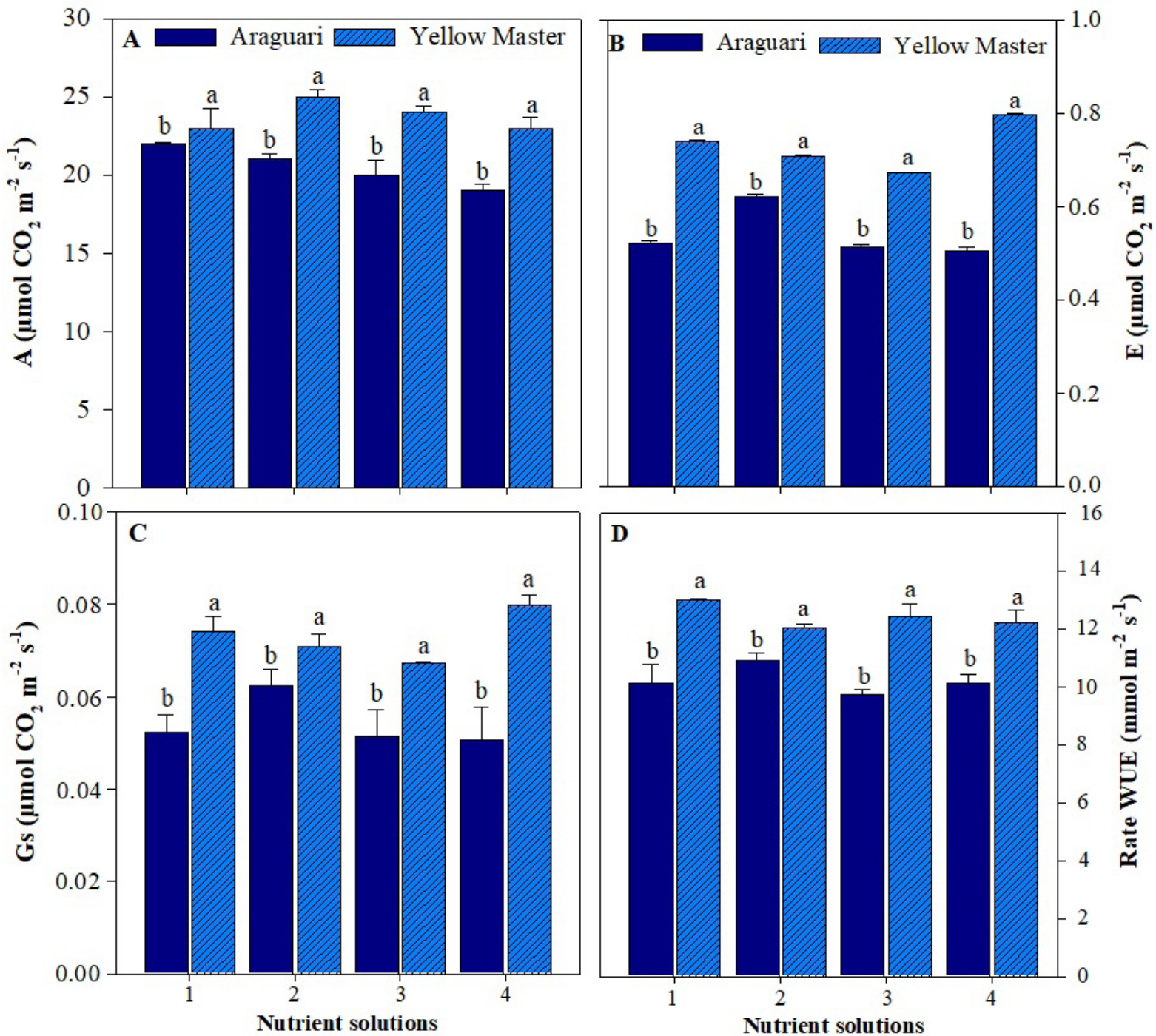

Figure 7. Net photosynthesis (Figure A), transpiration (Figure B), stomatal conductance (Figure C), and water use efficiency (Figure D) as a function of nutrient solutions and cultivars. Means followed by the same letter show no significant differences by the Tukey test at $5 \%$ probability $(\mathrm{P}>0.05)$. 


\section{Conclusion}

It is concluded that the use of nutrient solution 2 in cultivar Yellow Master, with $2.72 \mathrm{dS} \mathrm{m}^{-1}$ electrical conductivity and the use of nutrient solution 4 in cultivar Araguari, with $2.95 \mathrm{dS} \mathrm{m}^{-1}$ electrical conductivity, yielded the highest number of fruits, pulp mass, fruit mass and gas exchange, in slabs system in the protected cultivation of passion fruit.

\section{Acknowledgements}

The authors would like to thank Conselho Nacional de Desenvolvimento Científico e Tecnológico (CNPq), for the scholarship granted and resources for the execution of the research.

\section{References}

ALMEIDA, E.V.; NATALE, V.; PRADO, R.M.; BARBOSA, J.C. Adubação nitrogenada e potássica no desenvolvimento de mudas de maracujazeiro. Ciência Rural, Santa Maria, v.36, n.4, p.1138-1142, 2006.

AOAC - Association Of Official Analytical Chemists. Official methods of analysis. $15^{\text {th }}$ ed. Washington, 1990. $1298 \mathrm{p}$.

BORGES, A.L.; CALDAS, R.C.; LIMA, A.A. Doses e fontes de nitrogênio em fertirrigação no cultivo do maracujá-amarelo. Revista Brasileira de Fruticultura, Jaboticabal, v.28, n.2, p.301-304, 2006.

BORGES, A.L.; RODRIGUES, M.G.V.; LIMA, A.A.; ALMEIDA, I.E.; CALDAS, R.C. Produtividade e qualidade de maracujá-amarelo irrigado, adubado com nitrogênio e potássio. Revista Brasileira Fruticultura, Jaboticabal, v.25, n.2, p.259-262, 2003.

CALVETE, E.O.; NIENOW, A.A.; WESP, C.L.; CESTONARO, L.; MARIANI, F.; FIOREZE, I.; CECCHETTI, D.; CASTILHOS, T. Produção hidropônica de morangueiro em sistema de colunas verticais, sob cultivo protegido. Revista Brasileira Fruticultura, Jaboticabal, v.29, n.3, p.524-529, 2007.

COSTA, J.R.M.; LIMA, C.A.A.; LIMA, E.D.P.A.; CAVALCANTE, L.F.; OLIVEIRA, F.K.D. Caracterização dos frutos de caracterização dos frutos de maracujá amarelo irrigados com água salina. Revista Brasileira de Engenharia Agrícola e Ambiental, Campina Grande, v.5, n.1, p.143-146, 2001.
FERNANDES, A.A.; MARTINEZ, H.E.P.; FONTES, P.C.R. Produtividade, qualidade dos frutos e estado nutricional do tomateiro tipo longa vida conduzido com um cacho, em cultivo hidropônico, em função das fontes de nutrientes. Horticultura Brasileira, Brasília, DF, v.20, n.4, p.564-570, 2002.

FERNANDES, A.A.; MARTINEZ, H.E.P.; PEREIRA, P.R.G.; FONSECA, M.C.M. Produtividade, acúmulo de nitrato e estado nutricional de cultivares de alface, em hidroponia, em função de fontes de nutrientes. Horticultura Brasileira, Brasília, DF, v.20, n.2, p.195200, 2002.

FERREIRA, D. Sisvar: um sistema computacional de análise estatística. Ciência Agrotecnologia, Lavras, v.35, n.6. p.1039-1042, 2011.

FORTALEZA, J.M.; PEIXOTO, J.R.; JUNQUEIRA, N.T.V.; OLIVEIRA, A.T.; RANGEL, L.E.P.Características físicas e químicas em nove genótipos de maracujá azedo cultivado sob três níveis de adubação potássica. Revista Brasileira Fruticultura, Jaboticabal, v.27, n.1, p.124127, 2005.

GONÇALVES, M.A.; VIGNOLO, G.K.; ANTUNES, L.E.C.; JUNIOR, C.R. Produção de morango fora do solo. Pelotas: Embrapa Clima Temperado, 2016. 18p.

IBGE - Instituto Brasileiro de Geografia e Estatística. Produção agrícola municipal. Rio de Janeiro, 2017. Disponível em: http://www.cnpmf.embrapa.br/Base de Dados/index_pdf/dados/brasil/maracuja/b1 maracuja.pdf. Acesso em: 23 maio 2019.

LIMA, M.A.; BEZERRA, M.A.; GOMES, E.F.; PINTO, C.M.; ENÉAS, J.F. Trocas gasosas em folhas de sol e sombreadas de cajueiro anão em diferentes regimes hídricos. Revista Ciência Agronômica, Fortaleza, v.41, n.4, p.654-663, 2010.

NEIVA JUNIOR, A.P.; SILVA, J.C.; TIESENHAUSEN, I.M.E.V.V.; ROCHA, G.P.; CAPPELLE, E.R.; COUTO, C.C.C. Efeito de diferentes aditivos sobre os teores de proteína bruta, extrato etéreo e digestibilidade da silagem de maracujá. Ciência e Agrotecnologia, Lavras, v.31, n.3, p.871-875, 2007.

POPOV, E.G.; TALANOV, A.V.; KURETS, V.K.; DROZDOV, S.N. Effect of temperature on diurnal changes in $\mathrm{CO} 2$ Exchange in intact cucumber plants. Russian Journal of Plant Physiology, Moscow, v.50, n.2, p.178182, 2003. 
RICE, E.W.; BRIDGEWATER, L. Standard methods. Standard methods for the examination of water and wastewater. $22^{\text {th }}$ ed. Washington: American Public Health Association, American Water Works Association, Water Environment Federation, 2012.

ROCHA, L.F.; CUNHA, M.S.; SANTOS, E.M.; LIMA, F.N.DE.; MANCIN, A.C.; CAVALCANTE, Í.H.L. Biofertilizante, calagem e adubação com NK nas características físicas e químicas de frutos de maracujazeiro-amarelo. Revista Brasileira de Ciências Agrárias, Recife, v.8, n.4, p.555-562, 2013.

RODRIGUES, L.R.F. Técnicas de cultivo hidropônico e de controle ambiental no manejo de pragas, doenças e nutrição vegetal em ambiente protegido. Jaboticabal: FUNEP, 2002. 762p.

SANTOS, G.P.dos.; LIMA, N.A.J.; CAVALCANTE, L.F.; CAVALCANTE, Í.H.L.; SOUTO, A.G.L. Crescimento e produção do maracujazeiro amarelo sob diferentes fontes e doses de fósforo em cobertura. Bioscience Journal, Uberlândia, v.30, n.5, p.525-533, 2014.

SANTOS, V.A.; RAMOS, J.D.; LAREDO, R.R.; SILVA, F.O.; EDVAN ALVES CHAGAS, E.A.; PASQUAL, M. Produção e qualidade de frutos de maracujazeiro-amarelo provenientes do cultivo com mudas em diferentes idades. Revista de Ciências Agroveterinárias, Lages, v.16, n.1, p.33-40, 2017.
SILVA, J.; QUEIROZ, A.C. Analise de alimentos métodos químicos e biológicos. Viçosa: Editora UFV, 2002. 47-73p.

SOARES, T.M.; SILVA, E.F.F.; DUARTE, S.N.; MELO, R.F.; JORGE, C.A.; BOMFIN-SILVA, E.M. Produção de Alface utilizando águas salinas em sistema hidropônico. Irriga, Botucatu, v.12, n. 235-248, 2007.

SOUSA, V.F.; FOLEGATTI, M.V.; FRIZZONE, J.A.; CORREA, R.A.L.; ELOI, W.M. Produtividade do maracujazeiro amarelo sob diferentes níveis de irrigação e doses de potássio via fertirrigado. Pesquisa Agropecuária Brasileira, Brasília, DF, v.38, n.4, p.497-504, 2003.

UCHOA, A.M.A.; COSTA, J.M.C.; MAIA, G.A.; SILVA, E.M.C.; CARVALHO, A.F.U.; MEIRA, T.R. Parâmetros físico-químicos, teor de fibra bruta e alimentar de pós alimentícios obtidos de resíduos de frutas tropicais. Segurança Alimentar e Nutricional, Campinas, v.15, n.2, p.58-65, 2008.

HAAG, HP; OLIVEIRA, GD; BORDUCCHI, AS; SARRUGE, JR. Absorção de nutrientes por duas variedades de maracujá. Anais da Escola Superior de Agricultura Luiz de Queiroz, Piracicaba, v.30, p.267279, 1973. 